\title{
THE INFLUENCE OF MASS FRACTION OF DRESSED COAL ON IGNITION CONDITIONS OF COMPOSITE LIQUID FUEL DROPLET
}

\author{
Nikita E. Shlegel ${ }^{1}$, Mark D. Kats ${ }^{1}$, Dmitriy O. Glushkov ${ }^{1 a}$ \\ ${ }^{1}$ National Research Tomsk Polytechnic University, 634050 Tomsk, Russia
}

\begin{abstract}
The laws of condition modification of inert heat and ignition in an oxidant flow of composite liquid fuel droplet were studied by the developed experimental setup. Investigations were for composite liquid fuel composition based on the waste of bituminous and nonbaking coal processing, appropriate carbon dust, water, used motor oil. The characteristics of boundary layer inertia heat of composite liquid fuel droplet, thermal decomposition of coal organic part, the yield of volatiles and evaporation of liquid combustion component, ignition of the gas mixture and coke residue were defined.
\end{abstract}

\section{Introduction}

Applying of coal in power plants is characterized by high heat input in comparison with coal-water fuel (CWF) [1-4]. However, CWF has many advantages like low cost, high environmental measures which are close to similar characteristics at the combustion of natural gas. Recently, it is actively discussed the producing and combustion of CWF based on waste of coal processing [1, 2]. At the same time, it is of interest to study the ignition and combustion of coal-water suspensions with adding the liquid combustion component to increase an energy deposit in combustion chambers of steamgenerating equipment without significant change in heat surface construction [5-7] at the transition to a new type of fuel. The process of combustion initiation is characterized by higher response rate as compared to similar characteristic for dust of high quality dressed coal, because such composite liquid fuel compositions include solid and liquid waste. The addition of dressed coal in a dust is one of the possible ways for intensification of heat up and ignition of composite liquid fuel droplets. Consequently, the purpose of the investigation is establishing the influence of the dressed coal addition on characteristics of composite liquid fuel droplet ignition.

\section{Experimental sutup and procedure}

Two groups of compositions were investigated. Compounds of the first group included three components with their various mass fraction: waste (filter cake) of bituminous coal processing dressed bituminous coal, used motor oil. Compounds of the second group also included three components with their various mass fraction: waste of nonbaking coal processing, dressed nonbaking

\footnotetext{
${ }^{\mathrm{a}}$ Corresponding author: dmitriyog@tpu.ru
} 
coal, used motor oil. The filter cake is a mixture of coal dust with a particle size of about $80 \mu \mathrm{m}$ and water, moreover, their mass fractions are about $55 \%$ and $45 \%$, respectively. Combustion value of the filter cake (wet) of bituminous coal (the enrichment factory "Severnaya" of the Kemerovo region, Russia) is about $14.03 \mathrm{MJ} / \mathrm{kg}$. Combustion value of the filter cake (wet) of nonbaking coal (the enrichment factory "Kaltanskaya-Energeticheskaya" of the Kemerovo region, Russia) is about 16.4 $\mathrm{MJ} / \mathrm{kg}$. The results of technical and elemental analysis of filter cakes and corresponding dressed coals are presented in Tables 1 and 2. The main characteristics of used motor oil are introduced in Table 3.

Table 1. The results of the technical analysis of coals and filter cakes

\begin{tabular}{|l|c|c|c|c|}
\hline \multicolumn{1}{|c|}{ Sample } & $W^{\mathrm{a}}, \%$ & $A^{\mathrm{d}}, \%$ & $V^{\text {daf }}, \%$ & $Q^{\mathrm{a}}, \mathrm{MJ} / \mathrm{kg}$ \\
\hline Filter cake (dry) of bituminous coal & - & 26.46 & 23.08 & 24.83 \\
\hline Bituminous coal & 2.05 & 14.65 & 27.03 & 29.76 \\
\hline Filter cake (dry) of nonbaking coal & - & 21.20 & 16.09 & 26.92 \\
\hline Nonbaking coal & 2.89 & 18.07 & 15.07 & 27.65 \\
\hline
\end{tabular}

Table 2. The results of the elemental analysis of coals and filter cakes

\begin{tabular}{|l|c|c|c|c|c|}
\hline \multicolumn{1}{|c|}{ Sample } & $\mathrm{C}^{\text {daf }} \%$ & $\mathrm{H}^{\text {daf }} \%$ & $\mathrm{~N}^{\text {daf }} \%$ & $\mathrm{~S}^{\text {daf }}, \%$ & $\mathrm{O}^{\text {daf }}, \%$ \\
\hline Filter cake (dry) of bituminous coal & 87.20 & 5.090 & 2.05 & 1.022 & 4.46 \\
\hline Bituminous coal & 79.79 & 4.486 & 1.84 & 0.868 & 12.70 \\
\hline Filter cake (dry) of nonbaking coal & 90.13 & 4.255 & 2.31 & 0.441 & 2.77 \\
\hline Nonbaking coal & 87.97 & 4.104 & 2.23 & 0.526 & 5.03 \\
\hline
\end{tabular}

Table 3. The main characteristics of liquid fuel components

\begin{tabular}{|c|c|c|c|c|}
\hline $\begin{array}{c}\text { Density at } 293 \mathrm{~K}, \\
\mathrm{~kg} / \mathrm{m}^{3}\end{array}$ & Humidity, \% & Ash, \% & $\begin{array}{c}\text { Ignition } \\
\text { temperature, } \mathrm{K}\end{array}$ & $\begin{array}{c}\text { Heat of combustion, } \\
\mathrm{MJ} / \mathrm{kg}\end{array}$ \\
\hline 871 & 0.28 & 0.78 & 491 & 44 \\
\hline
\end{tabular}

Experimental investigations of composite liquid fuel droplet ignition were conducted by the experimental setup (Fig. 1). We used blower 2 and air heater 3 to form a flow of heated air in a cylinder 1. Air temperature $T_{g}$ was varied within the range of $300-600{ }^{\circ} \mathrm{C}$. Chromel-alumel thermocouples 9 (type K) measured values of $T_{g}$. Movement velocity of heated air flow was varied in a range of $V_{g}=1-5 \mathrm{~m} / \mathrm{s}$ and was monitored by an anemometer UnionTest AN110. We used the coordinate mechanism 4 to inject the droplet into a cylinder. Characteristic radius of droplets was determined with high-speed video cameras 8 and software Tema Automotive. 


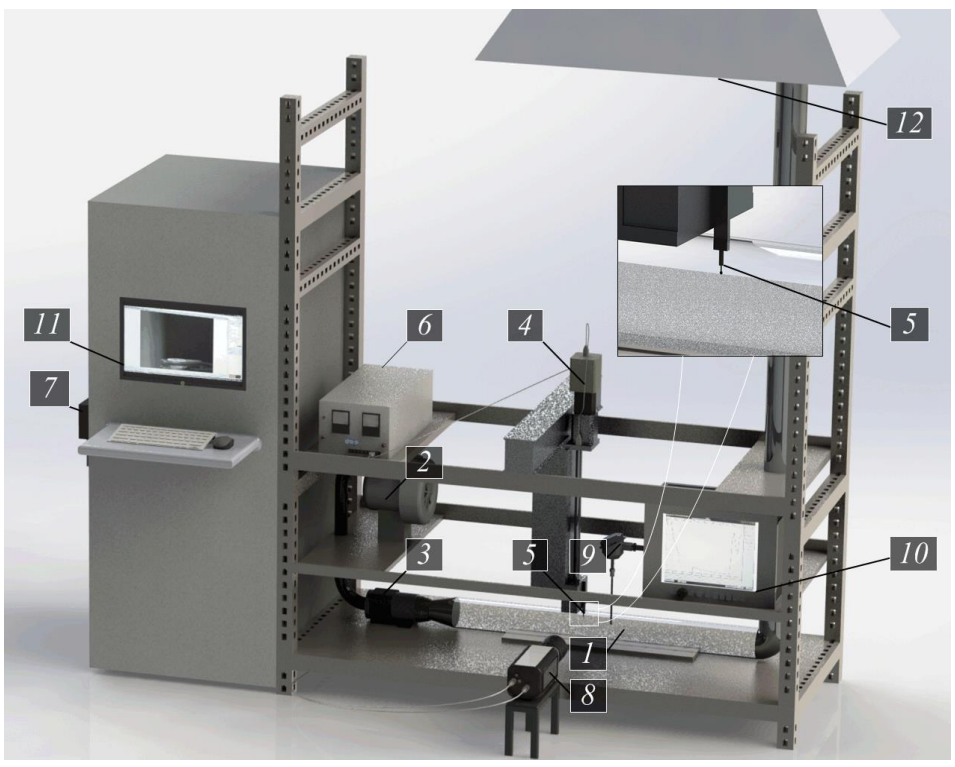

Figure. 1. Scheme of experimental setup: 1 - hollow glass cylinder; 2 - blower; 3 - air heater; 4 - coordinate mechanism of droplet supply; 5 - fuel droplet; 6 - power supply of coordinate mechanism; 7 - remote control for heater; 8 - high-speed video camera; 9 - thermocouple; 10 - registrar; 11 - computer; 12 - exhaust ventilation

Ignition delay times $\left(\tau_{d}\right)$ and periods of complete burning $\left(\tau_{c}\right)$ of composite liquid fuel droplet were taken as the main recorded parameters of studied process. The parameter $\tau_{d}$ is a time interval from an injection of composite liquid fuel droplet into channel 1 to identification of first characteristic frames of coke combustion. Time $\tau_{c}$ is a period from an injection of composite liquid fuel droplet into channel 1 to complete burning of coke residue.

\section{Results and discussion}

Figure 2 illustrates typical frames of composite liquid fuel droplet during heating, ignition and complete burning in a heated air flow.

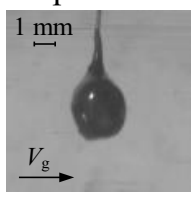

$\tau=0.01 \mathrm{~s}$

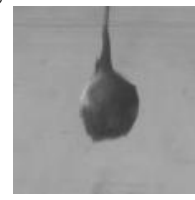

$\tau=6.75 \mathrm{~s}$

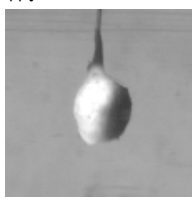

$\tau=8.68 \mathrm{~s}$

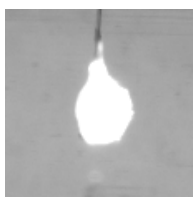

$\tau=10.78 \mathrm{~s}$

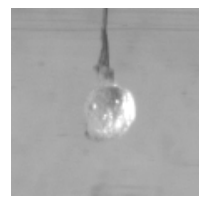

$\tau=24.32 \mathrm{~s}$

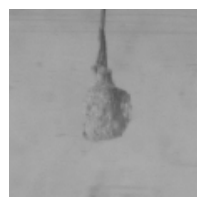

$\tau=31.67 \mathrm{~s}$

Figure 2. Typical frames with ignition and complete burning of composite liquid fuel droplet (filter cake of bituminous coal $85 \%+$ motor oil $10 \%+$ dressed coal $5 \%$ ) at $R_{d} \approx 1 \mathrm{~mm}, T_{g} \approx 600{ }^{\circ} \mathrm{C}, V_{g} \approx 5 \mathrm{~m} / \mathrm{s}$

Increasing the dressed coal concentration in a composite liquid fuel composition influences the characteristics of the process under study. Firstly, droplet heat up duration becomes shorter significantly. This is due to decrease of relative concentration of liquid component (primarily, water). The heat of endothermal phase transformation at droplet evaporation exceeds the energy of coal thermal disintegration by more than ten times. As a consequence, less energy accumulated by boundary layer of the droplet is required for composite liquid fuel ignition, when increasing the highrank coal concentration. Secondly, temperature of dressed coal ignition is significantly lower than similar parameter for filter cake. Combustion value, vice versa, is notably higher (Table 1). As a consequence, the increase of mass fraction of high-rank coal leads to growth of volatile concentration in a vicinity of composite liquid fuel droplet and cutting the ignition delay time. Thirdly, coal particle injection into the composite liquid fuel increases the viscosity and temperature conductivity of fuel 
composition (contribution of conductive heat transfer in a droplet heat up is rising). The absorption coefficient of heat emission is grown too (due to the high values of this parameter for coal particles). This effect intensifies significantly the radiative heat exchange at the «composite liquid fuel droplet gas medium» bound. At the same time, the convection component of heat transfer has less impact. The highlighted changes in the role of heat transfer mechanisms allow explaining the reasons of variation of ignition delay time $\left(\tau_{d}\right)$ and period of complete burning $\left(\tau_{c}\right)$ of composite liquid fuel droplet while varying the component concentration, e.g. additional dressed coal (Table 4).

Table 4. Periods of ignition and complete burning of composite liquid fuel droplets at $R_{d} \approx 1 \mathrm{~mm}, T_{g} \approx 600{ }^{\circ} \mathrm{C}$, $V_{g} \approx 5 \mathrm{~m} / \mathrm{s}$

\begin{tabular}{|l|c|c|c|c|c|c|}
\hline \multicolumn{1}{|c|}{ Composition } & \multicolumn{3}{c|}{$\begin{array}{c}\text { Filter cake of bituminous coal + engine oil } \\
\text { waste } 10 \%+\text { bituminous coal }\end{array}$} & $\begin{array}{c}\text { Filter cake of nonbaking coal + engine } \\
\text { oil waste } 10 \%+\text { nonbaking coal }\end{array}$ \\
\hline Dressed coal, \% & 0 & 5 & 10 & 0 & 5 & 10 \\
\hline$\tau_{d}, \mathrm{~s}$ & 8.88 & 6.76 & 6.17 & 10.94 & 9.24 & 8.35 \\
\hline$\tau_{c}, \mathrm{~s}$ & 22.73 & 16.88 & 14.93 & 19.72 & 15.76 & 13.86 \\
\hline
\end{tabular}

The results (Table 4) indicate the influence of component composition of composite liquid fuel on characteristics of droplet ignition and combustion. The relatively low increase in the concentration $\left(\varphi_{c} \approx 5 \%\right)$ of dressed coal leads to reduce the delay time of ignition (by 15-20\%) and a complete burning (by 20-25\%) of droplets under otherwise equal conditions. This indicates the possibility of combustion process optimization due to variation in mass fraction of such component even in a small range. Approximating dependences, which illustrate influence of this parameter on ignition delay time, are in Figure 3 for composite liquid fuel droplets of various sizes.

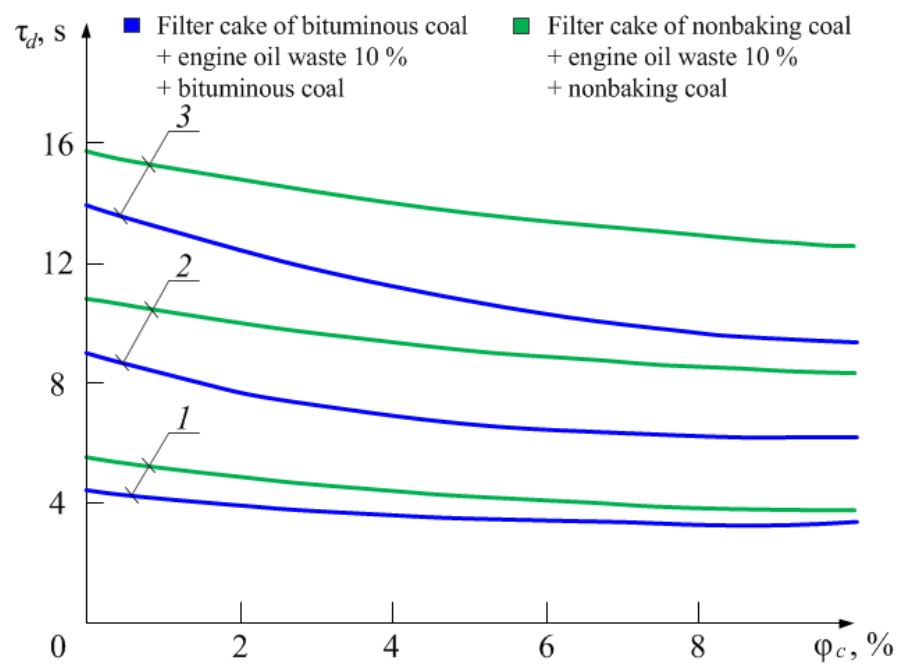

Figure 3. Ignition delay times of composite liquid fuel droplets (radii are $1-0.5 \mathrm{~mm}, 2-1 \mathrm{~mm}, 3-1.5 \mathrm{~mm}$ ) at varying the mass fraction of dressed coal

The results presented in Figure 3 characterize a significant dependence of ignition delay time of composite liquid fuel on droplet size. Smaller droplets induce faster droplet heat up, more intense phase transformation, and increase in speed of exothermal reactions. It was found that for ignition of considered compositions of composite liquid fuel, the minimum temperature of air flow is not less than $480{ }^{\circ} \mathrm{C}$. Whereby, the increase in dressed coal concentration in a composite liquid fuel composition to $10 \%$ leads to reduce of oxidant temperature, which is necessary and sufficient for stable ignition of droplets by $20-30{ }^{\circ} \mathrm{C}$. 


\section{Conclusion}

The results of experimental investigations allowed defining that relatively small (to $5 \%$ ) concentrations of dresses coal in the composite liquid fuel can significantly (not less than $15 \%$ ) influence the integral characteristics of droplet ignition and combustion. The obtained result carries inference of efficiency of such approach to optimizing the combustion process of composite liquid fuel droplet.

The study was supported by the Russian Science Foundation (project No. 15-19-10003).

\section{References}

1. W. Gajewski, A. Kijo-Kleczkowska, J. Leszczynski, Fuel, 88, 221 (2009)

2. A. Kijo-Kleczkowska, Fuel 90, 865 (2009)

3. J. Zhu, G. Zhang, G. Liu, Q. Qu, Y. Li, Fuel Processing Technology, 118, 187 (2014)

4. D. O. Glushkov, P. A. Strizhak, O. V. Vysokomornaya, Thermal Science, 19 (1), 285 (2015)

5. L. Bartoňová, Fuel Processing Technology, 134, 136 (2015)

6. A. P. Burdukov, V. I. Popov, M. Yu. Chernetskiy, A. A. Dekterev, K. Hanjalic, Applied Thermal Engineering, 74, 174 (2014)

7. R.-G. Kim, C.-H. Jeon, Applied Thermal Engineering, 63, 565 (2014) 